\title{
The Approach to Reform Islamic religion
}

\author{
Prof. Dr. Omer Najmaldden Inja Aljabbary* \\ College of Law, Kirkuk university- Iraq \\ Received 01 Nov 2017, Accepted 01 Jan 2018, Available online 07 Jan 2018, Vol.6 (Jan/Feb 2018 issue)
}

\begin{abstract}
This study (The Approach to Reform Islamic religion) deals with the following: 1 - Islamic religion is a set of rules, laws and instructions created by Allah Almighty to organize human society by bringing benefit to them and the preservation of their necessary interests and preventing any harmful and corrupted things from them. Moreover, it prevents overwhelming anyone in his religion, life, wealth and mind.2- Peace is among the fundamentals of the Islamic religion and it is a means of building the country, spreading religion and cooperation among the members of society in addition to organizing international relations between Islamic countries and others to preserve the common interests of the human being, considering that all people are brothers and they came from one father and one mother, Adam and Eve, and that war is an exception should be resorted only in the cases of defense and aggression. Even in the case of war, it must be resorted to peace and reconciliation. 3. Religion is a means of reforming the relationship between the individuals and the individual with the group to achieve peaceful coexistence. 4 - The Islamic religion is not a religion of violence, killing and aggression as alleged by the hypocrites who want to abuse the religion of heaven; because the appeal of the Islamic religion is an abuse to the rest of the heavenly religions; as the source of religions is Allah Almighty. Moreover, the religion was found to serve the community by organizing and preserving their interests. 5. Responsibility for the preservation of religion is a collective responsibility shared by the individual, society, clergy and the government. It must be legislated and directing the people not to offend religions and by insulting the heavenly religions as it is the source of Chaos and aggression among people.
\end{abstract}

Keywords: Islamic religion etc.

\section{Introduction}

Praise be to Allah, Lord of the Worlds, and prayers and peace be upon His Messenger, Muhammad (peace and blessings of Allah be upon him), whom Allah has sent mercy to the worlds, and to his family, companions, and those who followed them.

There is no doubt that Allah Almighty created the universe with His eloquent wisdom, including the living things, and made people the best of its varieties, so he created the human in the best of his picture, and made a suitable environment for him to live in peace and safety, but the hand of man began to mess everything as treachery, betrayal and harm to others. God Almighty was merciful. He did not neglect his slaves at all times and places. He sent to them prophets and messengers from time to time and from another place to show the provisions of Allah to serve humanity by organizing society and to preserve their interests, Until God sent the last one of The prophets and messengers (Muhammad) (peace be upon him) to show the last books of heaven,

*Corresponding author's ORCID ID: 0000-0002-2465-8523 DOI: https://doi.org/10.14741/ijmcr.v6i01.10905
The Holy Quran (Islamic law) for the same purpose is to provide service to the human community and to make a positive element beneficial to himself and others, Islamic law as the rest of the previous heavenly laws were and still means to repair the individual by preventing anyone assaults others.

However, the people of seductions and lusts tried to distort the divine religions and accused of falsehood as well as the accusation of prophets and messengers, it is not surprising when we find in the present time the accusation of the Islamic religion and the last prophets and messengers of qualities that are not worthy of them and far from the facts. So, one of the objectives of this study is to show the fact of the Islamic religion.

\section{This study is divided into two chapters}

The first chapter: The Islamic religion, contains a preface and eight sections: Section one: The meaning of the Islamic religion and the Islamic law; Section two: the reason for the existence of the Islamic religion: Section three: The purpose and the meaning of the Islamic religion; Section four: the meaning of the acts of worship 
Section five: obligation of people to submit to the command of Allah; Section six: religion and human behavior; Section seven: the Prophet and good morals; Section eight: Judgment and Man's Behaviours

The second chapter: Islamic religion and its external relationship. It contains of a preface and four sections; Section one: Peace is the basis of Islam; Section two: War is an exception in the Islamic religion; Section three: the divine religions and the Islamic religion; Section four: how to defend and preserve the religion. Then the conclusion of the most important results

\section{Chapter One Islamic religion, it contains of a preface and eight sections}

\section{Introduction}

There is no doubt that the speech about the Islamic religion is broad, general and comprehensive. It covers all aspects of the life of humanistic society, so we limit ourselves to some aspects of its truth and the purpose of finding it so that we can distinguish between the actions of man in terms of his acceptance of the Islamic religion or his failure to mix it.

The first section: The meaning of the Islamic religion and the Islamic law The Islamic Religion:

Religion in Language: its plural form is Religions, Religion: means Obedience ${ }^{(2)}$. Religion in the term: Religion is divine status that calls the minds to accept what is brought by the Prophet. On the other words: the status of the divine that drives of the minds of the good choice ${ }^{(3)}$.

The Islamic Sharia, Islamic Law:

The Sharia in the language: the way that shown in religion ${ }^{(4)}$. It is what Allah has prescribed the slave of the religion and ordered them to adhere to it from prayer, fasting, $\mathrm{Hajj}^{(5)}$. Sharia in the terminology: the way that manifests in religion and the law that Allah Almighty shows to His slaves. The four projects are: acts of worship, transactions, punishments, and penances, and their four fundamentals: the Qur'aan, Sunnah, the consensus of the nation and the measurement ${ }^{(6)}$.

So the law is what Allah has prescribed for $\mathrm{His}$ servants, the project that is shown by sharia, and religion is what stated in sharia of worship. It is called obedience, worship, punishment ${ }^{(7)}$.

\footnotetext{
${ }^{2}$ AlFarahidi, Aleayn book 8/73

${ }^{3}$ AlTawqif eala Muhimmat Altaearif, Author: Mohamed Abdel Raouf AlManawy 1/344

${ }^{4}$ Ibn-Almatraz - Almaghrib $1 / 439$

${ }^{5}$ AlFarahidi, Aleayn book $1 / 253$

${ }^{6}$ AlQawnawi - Anis Alfoqaha 1/309, AlJarjanie - Altaerifat 1/167

${ }^{7}$ Alhudud Al'aniqah wa Altaerifat Aldaqiqa, Author: Zakariaa bin Muhamad bin Zakariaa AlAnsari Abu Yahyaa 1/70
}

It is clear that religion is more specific than practical law. Every religion is Sharia, but not every Shari'a is religious, because it also includes branches of religion from the practical legal rulings that may be called Jurisprudence ${ }^{(8)}$.

So what we mean by that is that the religion of Islam is the religion that Allah revealed to His Messenger Muhammad (peace and blessings of Allah be upon him) to show it to all the people that they must obey Him; as Islam is the last of the heavenly religion, Allah says (interpretation of the meaning) "This day I have perfected for you your religion, and have been pleased to assign for you Islam as your religion" (Al-Ma'ida: 3), and also says (interpretation of the meaning): "The true religion with Allah is Islam" (Aal-Imran: 19)

The Islamic law is the law that the Prophet Muhammad (peace and blessings of Allah be upon him) brought from Allah Almighty through the divine revelation, and it was explained to the people to organizing their affairs and preserving their interests.

So we can say that the Islamic religion or Islamic law is a set of rules, foundations and laws created by Allah Almighty through his wisdom to serve the human community, to organize human society by bringing benefit to them and the preservation of their necessary interests and preventing any harmful and corrupted things from them.

\section{The second section: the reason for the existence of the Islamic religion}

The reason for the existence of the Islamic religion and sending the Prophet (peace be upon him) is the behavior of the human after spreading the corruption in the society and losing of people's rights and interests, so the man corruption everything according to his desires, whether related to worship or transactions. As for acts of worship: people were on the wrong worship and were associated gods with Allah Almighty.

As for transactions: people did not preserve the lives of others, their money, their honor's or their minds. They were doing what they wish without having any consideration to the censorship or the law that prevent them from such misconduct, so that human interests have been damaged, So that these acts corrupted the customs that their minds accepted, the Islamic law came to correct those transactions, so most of the provisions related to them showing the importance of regulating relationships among the members of the society.

Therefore, the actions of man was the reason for the existence of the Islamic religion and the Messenger of Muhammad (peace be upon him), as the behavior of people in previous societies was the cause of the existence of religions and messengers at their time.

\section{The third section: The purpose of the Islamic religion}

The purpose of the Islamic religion and its existence is to

\footnotetext{
${ }^{8}$ AlZilmie - Ausul Alfaquh fi Nasijihi Aljadid, P. 91

43 | Int. J. of Multidisciplinary and Current research, Vol.6 (Jan/Feb 2018)
} 
deal with these bad behaviors acquired by the human beings, whether related to acts of worship or transactions to achieve two things:

The first thing: to make people in the right worship that achieves the satisfaction of Allah Almighty. The second matter is to preserve their necessary interests to prevent the aggression of one another on his religion, life, honour, wealth, mind ${ }^{(9)}$, and other interests. Therefore, Allah Almighty ordered and protected them and imposed sanctions on anyone who assaults or harms them. Therefore, he (peace and blessings of Allah be upon him) In his famous sermon

He says (peace be upon him) in his famous speech (your blood, your money your honour are haram (forbidden) to you as the sanctity of your present day in your country, and he reiterated it repeatedly, then raised his head and said : o God have I conveyed ? I in Abbas (may Allah be pleased with them) said: I swear by the one who commands my soul, this is his will to his nation, let the witness inform tose absent, do not return infidels (kuffaran) after me, some hit the necks of some . (10)

Therefore, Allah Almighty did not find these provisions in vain, but it must be intended, because the texts of The Holy Quran apparently include rules that we can find through the words of the texts, but it internally includes the interests of bringing benefit and prevention corrupt. The benefit of these interests goes to society with its various components for organizing and stabilizing it. At the same time, it is pleasing to Allah Almighty.

Therefore, the Holy Qur'an is a constitution. It is the constitution of Allah that is worthy to be a source of reference in addressing the problems and obstacles that any society will face at any time and place regardless of sex, colour and language as a guarantor of rights and duties at all. It is necessary to adopt this methodology in educational and scientific centers to prepare the preachers who are serving the divine purposes in the statement of judgments.

This is a response to some of the ignorant tendencies who describe The Holy Quran, its provisions and sciences, as it is only some of the purely religious teachings, in other words, as if it is purely worshiping in the sense of isolation and intolerance, staying in mosques and places of worship and the abandonment of people and society. But in fact, the Holy Quran and Islamic law created by Allah Almighty to achieve and preserve the human interest.

\section{The fourth section: the meaning of the acts of worship}

The purpose of the acts of worship is not for its own sake, because Allah does not need people to worship by

\footnotetext{
${ }^{9}$ AlGhazali - almustasfaa $1 / 634$, Alrazie - almahsul fi eilm al'usul 5/222, AlZilmie - Ausul Alfaquh fi Nasijihi Aljadid P.122, Abdullah bin Ahmad bin Qadamat Almaqdisii Abu Muhamad - Rawthat Alnaazir wa Janat Almanathir 1/169

10 Alfawakih Aldawaniu 2/281, sahih AlBukhari 2/619 (bab alkhutbat 'ayam minaa) No.:1652, sahih Muslim 3/1307 (bab sihat alaiqrar bialqtl) No.:1679
}

praying, fasting, Hajj, Zakat and other acts of worship Similarly, Allah is not affected by our evil deeds ${ }^{(11)}$. Consequently, His provisions either aim at people's interests or remain aimless? The saying without a goal is invalid, because it is absurd, and Allah is exalted from doing it in vain.

It is to say that His provisions aim at the interests of the people $e^{(12)}$.

Therefore, acts of worship must be transformed into acts and sayings of good deeds for the purpose of reforming the individual and the community to achieve the purpose of Allah Almighty in the imposition of acts of worship, as in the following examples:

The prayer is obligatory. Allah says (interpretation of the meaning): "(O Prophet, recite the Book that has been revealed to you and establish Prayer. Surely Prayer forbids indecency and evil" Al-Ankabut 45, i.e. - prayer is a reason for ending the sin when it is occupied. Praying has three virtues and every prayer does not have these virtues is not prayer: Sincerity, Fear and Glorification of Allah. Sincerity orders him to do well, fear represents the end of the evil and Glorification of Allah orders him to do well and avoiding the evil ${ }^{(13)}$, ie - the prayer is a reason to end the sins ${ }^{(14)}$.

Therefore, the Prophet (peace and blessings of Allah be upon him) said: " Whoever does not praise his prayer for indecency and evil does not increase from Allaah except by a dimension ${ }^{(15)}$

The obligation of fasting: Allah says(interpretation of the meaning): "Believers! Fasting is enjoined upon you, as it was enjoined upon those before you, that you become Godfearing" (Al-Baqara: 183) You will avoid sins and fasting breaks the lust in its origin ${ }^{(16)}$.

In fasting it is altruistic of obeying Allah over the lusts of the body and to accustom the Muslim to the meanings of sincerity, will and patience ${ }^{(17)}$.

Obligation of zakat (alms): Allah says (interpretation of the meaning): "The alms are meant only for the poor and the needy and those who are in charge thereof, those whose hearts are to be reconciled, and to free those in bondage, and to help those burdened with debt, and for expenditure in the Way of Allah and for the wayfarer. This

\footnotetext{
${ }^{11}$ AlZilmie - Ausul Alfaquh fi Nasijihi Aljadid, P. 132

${ }^{12}$ AlZilmie - Ausul Alfaquh fi Nasijihi Aljadid, P. 132

${ }^{13}$ Tafseer Ibn Katheer $1 / 459$

${ }^{14}$ Tafseer AlBaydawi 1/318, Tafsir Al-Jalalayn 1/526, Al-Suyuti Aldur Almanthur 6/464

15 Altabrani- almuejam alkabir 11/54, Alhadith No.: 11025, musand alshhab $1 / 305$, Alhaythamii said in majmae alzawayid 2/531: rawah altubranii fi alkabir warijalih rijal alsahihi, takhrij 'ahadith al'iihya' $1 / 104$

${ }^{16}$ Tafsir albaydawi $1 / 461$, tafsir aljalalin $1 / 35$

${ }^{17}$ Dr. Abd Alkarim Zaydan- 'usul aldaewa P. 43
}

44 | Int. J. of Multidisciplinary and Current research, Vol.6 (Jan/Feb 2018) 
is an obligation from Allah. Allah is All-knowing, All-wise" (At-Tawba: 60)

Zakat is a purification of the Muslim from the disease of poverty, stinginess and the worshiping of money, in additin to contribution in achieving the cooperation that required to help those with needs ${ }^{(18)}$ The obligation of Hajj: Allah says(interpretation of the meaning): "Pilgrimage to the House is a duty owed to Allah by all who can make their way to it. As for those who refuse to follow His command, surely Allah stands in need of no one in the whole universe" (Aal-Imran: 97)

Hajj is a practical education for the Muslim. The approach of Islam in education is not sufficient to say to the Muslim that he is good only, but it is said that to him in addition to the sets of practical methods for him to be good. Among these practical methods is Hajj which shows the slavery of the Muslim to Allah in a practical way and clearly removes the roots of tyranny and germs from the same Muslim ${ }^{(19)}$

Therefore, it is clear that the Shari'a in its building and foundation is based on the ruling and the interests of the people. It is justice, mercy, interests and wisdom. All matters those come from justice to injustice, from mercy to its opposite, from the interest to the corrupt and from the wisdom to the tampering are not the Shari'a. The Shari'a is the justice of Allah among His creation, His mercy among His creation, His shadow in His land and His wisdom that refers to $\mathrm{Him}^{(20)}$

It can be understood that the intention of the acts of worshiping are to refine the behavior of the individual and turn these acts of worship into deeds and good words to be a good member in the organization of the society.

\section{The fifth section: obligation of people to submit to the command of Allah}

The submitting to the command of Allah in the sense of what Allah Almighty revealed by the provisions which are the laws of the utterance and meaning as in The Holy Quran, or what created meaning without utterance as in Sunnah, and to achieve the intent of Allah Almighty in legislating the provisions, all people must submit to the command of Allah, Because he finds those provisions concern all matters of his life, from birth to his death and even after death. These provisions affect the behavior of the individual to change him from evil to good, and from good to better; because in nature of human there is tendency to tyranny that must be removed, as Allah says (interpretation of the meaning): "Nay, Surely man transgresses" (Al-Alaq: 6), by removing those bad human trait, he will be a good element in the society useful for himself and others.

\section{The sixth section: religion and human behavior}

\footnotetext{
${ }^{18}$ Dr. Abd Alkarim Zaydan- 'usul aldaewa P. 43

19 Dr. Abd Alkarim Zaydan- 'usul aldaewa P. 43

${ }^{20}$ Alshaatby- 'iielam almuqiein $3 / 3$
}

It can be noticed that the Islamic religion is a set of obligations established in the Holy Quran and the Sunnah prescribed by Allah Almighty for human service as a transcendent person of human interests and these provisions have only begun to regulate all the affairs of human life and the resulting acts: Colloquial and actual, In order to reach to the highest levels of perfection in good behavior. The society will get benefits and be happy by increasing the members of the component and established in accordance with the correct approach, where it is a means to increase the good in the community for the purpose of organization and arrangement so the society will be sound and straight, and each individual maintains his rights and obligations.

This is in contrast to the fact that many of its members are evil, corrupt and far from the religious approach, so the behavior of the individual is a means to cause chaos and corruption in society and thus violate the rights of individuals.

\section{Religion made people feel two things:}

First: He feels that there is an observer who knows everything, watching him in his secret and his publicity at every time and place, Allah Almighty who accounts him for everything if it is bad, or rewards him if it is good.

Second: People feel that the reality of himself and the purpose of his existence and the existence of the religion of Allah which is in his favor, so adhere to the provisions of Allah to be virtuous (honesty, performance of secretariat and cooperation on the good), and abandoning the vices (lie, betrayal of secretariat and cooperation on evil). As a result he will be a good member in his society. And therefore he has achieved the satisfaction of Allah Almighty on one side and society on the other.

This shows that good behavior has been and continues to be a means to spread the religion of Allah in the universe because the mind of human accepts it well.

\section{The seventh section: the Prophet and good morals}

As we have seen that Allah Almighty wants the person to reach the highest levels of charity, good and virtues, so we find that Allah Almighty made the messengers and prophets to be good morals and to be a good example of people and turn their behavior to people to resolve them, and since the Islamic religion is the last religion and His Messenger Muhammad (peace and blessings of Allah be upon him) is the last of the Prophets and Messengers, so we find that Allah Almighty has collected all good morals and virtues in it, says the Prophet Muhammad (peace be upon him) (But sent to complete the ethics) ${ }^{(21)}$, in another novel ${ }^{(22)}$ (But sent to complete the good ethics) Morality), i.e. virtues not vices ${ }^{(23)}$

\footnotetext{
${ }^{21}$ Alhakim alnysabwry- almustadrak ealaa alsahihayn 2/670 and said: hadha hadith sahih ealaa shart muslim w lam yukhrajahu, sunan albihqi alkibraa10/191

22 Masanad 'Ahmad bin hinbal 2/381 taeliq shueayb al'arnuwt : sahih wahadha 'iisnad qawiun rijalih rijal alsahih ghyr Muhamad 45 | Int. J. of Multidisciplinary and Current research, Vol.6 (Jan/Feb 2018)
} 
Making it as a good example to stick to it, where Allah says (interpretation of the meaning): "Surely there was a good example for you in the Messenger of Allah" (AlAhzab: 21)

So Allah commanded us to obey him by saying (interpretation of the meaning): "Believers! Obey Allah and obey the Messenger" (Al-Nisa: 59).

Allah commanded us to obey Him and the Messenger, and obedience of Allah refers to The Holy Quran and obedience of the Prophet be by reference to Sunnah, so that the following of Allah will be achieved by the following of His Messenger, because we have not seen Allah with our eyes, but we realized Him with our minds and through the message of His Messenger, as Allah says (interpretation of the meaning): "(O Messenger), tell people: 'If you indeed love Allah, follow me, and Allah will love you and will forgive you your sins. Allah is AllForgiving, All-Compassionate'." (Al-Imran: 31), then the following of the Messenger of Allah was a means to achieve the pleasure of Allah, where the Prophet (peace be upon him) says: Whoever obeys me has obeyed God and whoever disobeyed me has disobeyed God ${ }^{(24)}$

So the following of the Messenger of Allah is not for himself but for the benefit of people and for the purpose turning to him and keeping them away from evil to good.

The Prophet (peace and blessings of Allah be upon him) did not say and do anything except for the benefit and interest of all people, and did not give up anything except for what is in it Harmful to all people, so the Prophet Muhammad (peace be upon him) is the mercy to the people in this world and hereafter Allah says (interpretation of the meaning): "We have sent you forth as nothing but mercy to people of the whole world." (AlAnbiya: 107)

Thus, it is clear that the person must adhere to the Sunnah of the Prophet to be characterized by good morals and good habits of words and deeds, the prophetic Sunnah is truly a means to reform the individual and society.

\section{The Eighth section: Judgment and Man's Behaviours}

It is well known that man is judged by his apparent actions. If his actions are good, he is judged as a good person, and if his actions are bad, he is judged as a corrupted and harmful person.

But when a person embraces Islam as his religion and is subject to the application of the methodology of the

bin Aujlan faqad rawaa lah muslim mutabaeat wahu qawiu alhadithu, al'adab almafrud 1/104, masnaf bin 'abi shaybat, $6 / 324$, shaeb al'iiman 6/230

${ }^{23}$ Aumdat alqari' 22/118

24 Sahih Albakhari 6/2611 Alhadith No.: 6718 bab (kitab al'ahkam- bab bab qawl allah taealaa $\{0$ you who believe! Obey God and obey the Messenger and those in authority among you. \}, Sahih muslim 3/1466 Alhdyth No.: 1835 bab (bab wujub taeat al'amra' fi ghyr maesiat watahrimiha fi almuesia)
Quran and Sunnah (Muhammad), and religion is a reason for his reform and good behavior, these actions are reflected positively on his religion, in the sense that his religion is a religion of good and cooperation, so this serves the community for the purpose of organizing, every Muslim in the Islamic and Western countries must have the highest virtues, good habits and customs that are useful for himself and others to be able through his actions to transfer the truth of his religion, as the Prophet (peace be upon him), his companions and those who followed them did.

In some cases, we may find that a person may convert to Islam as a religion but does not behave well; rather he harms the members of the society and harms them. Hence, religion should not be judged by these bad behaviors, which is a means to mislead the Islamic religion with falsehood. Harming others, or a religion of violence, intensity, hatred and the prevention of good, and any attribute not appropriate to the Islamic religion.

Therefore, the Islamic religion and the Messenger of Allah are often accused because of these ignorant persons by looking at some of the evil behavior of them. These behaviors are personal actions stemming from desires and lust, not legitimacy, which stems from good and reform.

Therefore, the true ruling on human actions must be compared with the book of Allah (The Holy Quran) and His Messenger (Sunnah) if they do not fit with the methodology of Allah and His Messenger, so religion of Islam refuses them.

Therefore, if we find that the Muslim misbehavior and resorted to the use of violence to kill others without right, we say that it is a personal act that requires punishment in Islam and not reward, Allah says (interpretation of the meaning): "Do not kill any person whom Allah has forbidden to kill, except with right." (Al-Isra: 33)

If we find him to attack the honour of others with adultery, we say that it is a personal act, not a legal one, and he must be punished in the Islamic religion. Allah says (interpretation of the meaning): "Those who fornicatewhether female or male- flog each one of them with a hundred lashes." (An-Noor: 2).

And if we find him assaulting the money of others with theft, fraud and embezzlement, we say that it is a personal and not a legitimate act, Allah says (interpretation of the meaning): "As for the thief- male or female- cut off the hands of both. This is a recompense for what they have done, and an exemplary punishment from Allah. Allah is All-Mighty, All-Wise." (Al-Ma'ida: 38)

The Prophet (peace and blessings of Allah be upon him) said: (It is none of us cheated $)^{(25)}$. he means whoever cheats is not one of us, neither from our companions nor in our way and our guidance and we are innocent of him ${ }^{(26)}$

\footnotetext{
${ }^{25}$ Sahih Muslim 1/99 bab bab Prophet Mohammad peace be upon him saying of cheating is not us- Alhdyth No.: 164

${ }^{26}$ Tafsir Alqurtabii 3/239 , 7/134 . Alshuwkani - Fath Alqadir $2 / 266$

46 | Int. J. of Multidisciplinary and Current research, Vol.6 (Jan/Feb 2018)
} 
If we find he cannot distinguish between good and evil, right and wrong because of a defect in his mind as a result of taking intoxicated substances and narcotic to the mind, we say this is also a personal behavior is not legitimate, and that the religion forbids to take all substances that are harmful to the mind where Allah says (interpretation of the meaning): "Believers! Intoxicants, games of chance, idolatrous sacrifices at altars, and divining arrows are all abominations, the handiwork of Satan. So turn wholly away from it that you may attain to true success." (AlMa'ida: 90)

If we find a Muslim not cooperating on good and reform but working on evil and aggression, we also say that his behavior is personal and not legitimate, because Allah Almighty commands people to be good and cooperative and He says (interpretation of the meaning): "Help one another in acts of rightness and piety, and do not help one another in sin and transgression. Fear Allah: Surely Allah is serve in retribution." (Al-Ma'ida: 2)

The Messenger of Allaah (peace and blessings of Allah be upon him) said: (Do not I tell you better than fasting, prayer, and charity? They said: Yes, O Messenger of God said: reform of the inter-said: And the corruption of the interrelationship is the case. ${ }^{(28)(27)}$

He say (Is not a liar who reconciles between people and narrates something good or say good ${ }^{(29)}$ )

Allah Almighty says (interpretation of the meaning): "To speak a kind word and to forgive people's faults is better than charity followed by hurt. Allah is All-Sufficient, All-Forbearing." (Al-Baqara: 263) ${ }^{30}$

Therefore, if they are adhered to the religion of Allah and the Sunnah of His Messenger, they will be a means of reforming thus be a good member in the society for the purpose of organizing it.

Basing on this fact, it must be concealed any of the seditious who calls and wants to insult the religion of Islam and His Messenger Muhammad (peace be upon him) by judging some of the bad behavior that they see and find from some Muslims, whether in Western countries or Islamic, and know those acts of Islam is an invalid way to accuse the Islamic religion of the violence, isolation and harming to others.

We say that the correct behavior is what was in accordance with the Islamic religion and serves the human interest that can be known by the Islamic religion, and the bad behavior issued by the human, against the

\footnotetext{
27 Halq aldubn

28 Musnad Ahmad bin Hanbale 6/444 Alhdyth No.:27548, Shueayb Alarnwwt comment's: isnadh sahih, Sunan Altarmadhi 4/663 No.:2509 bab: ma ja' fi islah dhat albyn, Altaramudhi said : hasan sahih - Shaykh Al'albani said: shih, sunan Abi Dawd 2/697 No.:4919 bab: fy islah dhat albyn- Alshaykh Al'albani: sahih

${ }^{29}$ Sahih Albukhari 2/958 No.:2546 bab:lays alkadhib aldhy yuslih bayn alnaasi, Sahih Muslim 4/2011 No: 2605 bab: tahrim alkadhib wabayan almubah

${ }^{30}$ Al-Baqara: 263
}

Islamic religion, cannot be known by the Islamic religion, but personal actions that are not legitimate.

This concept is also found in the Christian religion, as the Reverend Abu Al-Faraj Abdullah Ibn Tayeb al-Faqih says in the divine sciences and the Christian law: Now the Christians are not the law of the kingdom of heaven but with desires and weakness of humanity and among them are adversaries. Therefore they needed judgments because those who seek the kingdom of heaven in them are few and that they should not come before the Jorah, they must come before the saints ${ }^{(31)}$.

This is in order to regulate the relationship of the individual with each other individuals or a group to organize their internal society, while at the level of external relations; we will tackle in the second chapter:

\section{The second chapter: The second chapter: Islamic religion and its external relationship. It contains of a preface and three sections}

\section{Introduction}

If we look at the Holy Quran and Sunnah, its provisions are not limited to regulating the relationship of the individual with the individual or the community within one society or one religion, but extended to a broader one, namely how to organize international relations whether they are in the same religion or different religions to achieve the interest of sound life among societies and countries that is far from aggression and conflict.

\section{Section one: Peace is the basis of Islam}

The basis of the Islamic religion is peace to achieve the interest of peaceful coexistence in society regardless of religion, sex and language, so Allah Almighty commands to enter it, as ordered not to enter into anything that would lead to hatred and aggression which is the way of the devil, as Allah Almighty says (interpretation of the meaning): "Believers! Enters wholly into Islam and do not follow in the footsteps of Satan for hi is your open enemy." (Al-Baqara: 208)

So the believers have to believe in all the laws of Islam through their word and deed. They have to be away from the ways of the devil and its effects, for it is an enemy for humans that shows you his enmity and the way of Satan is the way of fouling the laws of Islam ${ }^{(32)}$ as Allah Almighty says (interpretation of the meaning): "he only commands you to do evil and commit acts of indecency and to ascribe to Allah the things concerning which you have no knowledge (that He really is their source)." (Al-Baqara: 169).

\footnotetext{
${ }^{31}$ Abu Alfarj Abdullah bin Altayb- Faqih Alnisraniya book 1/181

32 Tafseer al-Tabari 2/335, Tafseer Ibn Katheer 1/335, AlShawkani - Fatah al-Qadeer 1/321
}

47 | Int. J. of Multidisciplinary and Current research, Vol.6 (Jan/Feb 2018) 
The verse warns that the mission of the apostles is to remove the infidelity and misguidance that occurs in the centuries of ignorance, as well as the centuries that followed the mission of Muhammad (peace and blessings of Allaah be upon him) ${ }^{(33)}$.

Therefore, it is the duty of the Prophet (peace and blessings of Allah be upon him) to inform and indicate the rulings of Allah Almighty in his words, deeds and reports. Therefore, we find that the Prophet (peace and blessings of Allah be upon him) used the approach of peace in his behaviors among people, whether with the same religion (Islamic religion) or on different religions (such as Christian and Jewish), as peace is legally enjoined by Islam.

Even with the polytheists we find that Allah Almighty enjoins not to be exposed to their beliefs in order not to be a means to expose the beliefs of Muslims and be a means of war and to harm others as in the words of Allah Almighty (interpretation of the meaning): "Do not revile those other than Allah whom they invoke, because they will revile Allah in ignorance out of spite. For We have indeed made the deeds of every people seem fair to them. Thereafter, they will return to their Lord and $\mathrm{He}$ will inform them of what they have done." (Al-An'am: 108)

It is from this basic rule that the Prophet (peace and blessings of Allah be upon him) built the Islamic state depending on peace and security so that every human being can live in peace under it, preserving his rights and interests, whether Muslim or non-Muslim. the Prophet based on the reconciliation with non-Muslims such as Hudaybiyah and Hudna Bani al-Asfar, where he says (Then there will be a truce between you and Bani al-Asfar) ${ }^{(34)}$.

\section{The second section: War is an exception in the Islamic religion}

Since the Islamic religion does not call for war and aggression because it does not serve the human interest, so it makes the war as an exception so that it cannot resort to it except in the case of aggression and assaulting, as Allah Almighty says (interpretation of the meaning): "Thus, if someone attacked you, attack him just as he attacked you, and fear Allah and remain conscious that Allah is with those who guard against violating the bounds set by Him." (Al-Baqara: 194) Because the origin is peace as we have mentioned, even in the case of aggression if there is room for peace and reconciliation it must be resorted to it, as Allah Almighty says (interpretation of the meaning): "If they incline to peace, incline you as well to it, and trust in Allah. Surely He is AllHearing, All-Knowing." (Al-Anfal: 61), and He says (interpretation of the meaning): "Surely the believers are none but brothers unto one another, so set things right

\footnotetext{
${ }^{33}$ Altahrir Waltinwir 1/585

${ }^{34}$ Sahih al-Bukhaari 2/960 Bab al-Solh mae almushrkyn- hudna: alsulh- bani Alasfr: Alrwm
}

between your brothers, and have fear of Allah that you may be shown mercy." (Al-Hujurat: 10)

Therefore, the Islamic nation is described as the best nation, because it enjoins what is good and forbids evil, as Allah Almighty says (interpretation of the meaning): "You are now the best nation brought forth for mankind. You enjoin what is right and forbid what is wrong and believe in Allah." (Al-Imran:110 )This invalidates the call of the malicious parties who describe the Islamic religion as a religion of violence, aggression and harm to others.

\section{The third section: the divine religions and the Islamic religion}

The attitude of the Prophet (peace and blessings of Allah be upon him) was clear for the rest of the heavenly religions. He pointed out that the heavenly religions were created by Allah Almighty in the service of man. It is not for differences and contradictions, as some claim, because the source of the heavenly judgments is one, Allah Almighty, not to make a religion against another religion or to send a prophet against another prophet; but, heavenly religions completes each other; they are complementary, not contradictory, so we find that the provisions concerning the origins of religion (doctrinal judgments) or the branches of religion, especially those concerning the necessary interests ${ }^{(35)}$ did not differ from prophet to another and from time and place to others, but these provisions are consistent in all the books of heaven ${ }^{(36)}$;

Therefore, the provisions of Allah Almighty to the former nations prescribed Islam unless mentioned in The Holy Quran and the Sunnah according to some scholars because The Holy Quran is the mother of the provisions of Allah Almighty to the past nations mediated by the prophets and messengers in addition to new provisions created by Allah Almighty to serve the interests as the result of the evolution and the difference of time ${ }^{(37)}$, so Allah Almighty says (interpretation of the meaning): "He has prescribed for you the religion which He enjoined upon Noah and which We revealed to you (O Muhammad), and which We enjoined upon Abraham and

\footnotetext{
${ }^{35}$ The necessary interests are (the interest of the preservation of religion, life, supply, money, mind)

${ }^{36}$ Irshad Alfuhul 1/319, Ali bin Muhamad Alamadi Abu Alhasan Al'iihkam fi usul al'ahkam 3/300 -301, Ali bin Muhamad bin Al Albaeli Abu Alhasssn- Almukhtasir fi usul alfqih based on madhab Al'imam Ahmad bin Hanbel 1/163, Ibrahim bin Musaa Allakhmi Alghirnati Almaliki- almuafaqat fi usul alfigh 4/:27-29 Altahrir Waltanwir $1 / 260$

${ }^{37}$ Alghazaly Almustasfaa $1 / 165$, Ali bin Muhamad Albazdwyusul Albazdwy 1/232, Muhamad bin Ahmad Alsarkhasi- usu Alsirkhsi 2/76, Alsbky- alabhaj 2/276-279, Ibn Hazm - Al'ahkam 5/169, Alamadi- al'ihkam 4/145, Aljawiny- Alburhan fi usu alfaqih 1/331, Alfiruz Abadhi Alshayrazi- Altabsira 1/285, Al'asnauy- altamhid 1/441, Ahmad bin Ali Alraazi Aljasas Alfusawl fi Al'asul 2/327. Dr. Nazmy Lawqa - Alniqa' Almasihia wal'islam P. 113
}

48 | Int. J. of Multidisciplinary and Current research, Vol.6 (Jan/Feb 2018) 
Moses and Jesus, commanding: "Establish this religion and do not split up regarding it." What you are calling to is very hard upon those who associate others with Allah in His Divinity. Allah chooses for Himself whomsoever $\mathrm{He}$ pleases and guides to Himself whoever penitently turns to Him." (Ash-Shura: 13)

It means the permission of halal and the prohibition of haram. Allah Almighty mentions Abraham, Moses and Jesus with our Prophet (peace and blessings of Allah be upon them) because they are the owners of the laws and then Allah Almighty ordered the establishment of religion preventing difference in it saying: (And do not differ in it) it means that there is no difference in monotheism and faith in Allah Almighty, obey his messengers and accept his laws. The laws have been consistent with these things so there should be agreement in them ${ }^{(38)}$, or because the laws although different in them, but they agree in the aspect of interests.

This fact confirmed by the Prophet (peace be upon him): Abu Hurayrah (may Allah be pleased with him) said: I heard the Messenger of Allah peace be upon him says (I am the first of the people of the Son of Mary, and the Prophets are the sons of Olat, not between me and $\operatorname{him})^{(39)}$.

it means that their laws are consistent in terms of assets, but different in terms of branches according to time and according to the general and particular ${ }^{(40)}$.

In another narration: "The Messenger of Allah (peace and blessings of Allaah be upon him) said:" I am the first people of Jesus son of Mary in this world and the Hereafter and the prophets are brothers to the wives of their mothers and their religion is one. ${ }^{(41)}$

As for the Jewish religion: We find that the Messenger of Allah (peace be upon him) in Medina when he wrote the document, he contained a number of items related to the Jewish religion and the preservation of their rights and interests, including:

38 Tafsir Alqurtabi 11/16, Fatih Alqadyr 4/754, Altahrir Waltanwir $1 / 260$

39 Sahih Albukhari 3/1270 (bab wadhkur fi alkitab maryam ith antabadhat min ahliha) Alhadith No.: 3258 , Sahih Muslim $4 / 1827$ (chapter of the virtues of Jesus peace be upon him) Alhadith No.: 2365.

(Awlaa Alnaas) The most special people and closest to him because he preached to him or because there is no prophet among them, as if they were in one time.

(Awlad Alaat) Brothers of the same father with different mothers

40 Sahih al-Bukhaari, 3/1270 (chapter of the virtues of Jesus peace be upon him) Hadith No .: 2365, Abu Zakaria Yahya bin Sharaf al-Nawawi - Alminhaj sharih sahih Muslim bin Hajaj 15/119 (chapter virtues of Jesus peace be upon him).

41 The previous sources, however, it is in Sahih al-Bukhaari under the number: 3259

(Various) and different.

(Religion is one) is the religion of monotheism and this indicates that the true proportions is the ratios of faith and faith and be the differential not by parents.
The Jews who followed us have victory and the equivalent without oppressed.

The Jews of Auf are a nation of believers, the Jews have their religion, and the Muslims have their religion, their followers and themselves except who misjudged himself as if he misjudged ${ }^{(42)}$ himself and his family. And if they call for peace, they will reconcile it, and if they are called upon to do so, then they have only those who fight against religion. All people have their own right on their side, which accepted them ${ }^{(43)}$.

This is one of the most important items where the Prophet (peace be upon him) prepared a constitution that includes provisions that have a positive impact on the society, each member of the community was able to maintain his rights under the Constitution regardless of religion and language, his work (peace be upon him) was the way of organizing the society.

\section{The Fourth section: How to defend and preserve religion}

Since it shows us the importance of the Islamic religion and its truth in the organization of society and the preservation of the necessary interests of the human race regardless of religion, sex, color and language, then it is necessary to preserve this religion and defend it in the best ways and calling the method of the Messenger of Allah (peace be upon him) As Allah says: "Invite to the way of your Lord with wisdom and good advice, and debate with them in the most dignified manner. Your Lord is aware of those who stray from His path, and $\mathrm{He}$ is aware of those who are guided.." Al-Nahl 125, and it made the people accept his minds.

In order to maintain and preserve the interests of the people, laws must be legislated at the international and regional levels to criminalize all those who assault religions and beliefs by saying or deed and not to allow for them to expose to religion in the name of democracy and freedom of opinion and thought; because they lead to hatred and infighting. ${ }^{(44)}$, then the responsibility for the preservation of religion is a collective responsibility.

\footnotetext{
${ }^{42}$ To perish

${ }^{43}$ Details of the document in: Dr. Ali Mohammed Al-Salabi Biography of the Prophet 320-321 ,. Dr. Mohammed Saeed Ramadan Albouti - jurisprudence Biography P. 156-157. And others.

${ }^{44}$ In conjunction with the September 11 events, an American film was shown on September 11, 2012, in which the Prophet Muhammad (peace be upon him) and Muslims in general were insulted. The film rented for approximately 15 minutes, produced by the owners of Jewish capital in America at a cost of $\$ 5$ million.

In the wake of that, a popular volcanic revolution in several Arab countries to support our master Muhammad (peace be upon him) and stand against the abuses and those behind them and staged demonstrations against American empassies in the Arab countries and resolved in violence in some, As happened in Libya when the ambassador was killed and some of the officers working in the embassy in Sana'a and the wounding of others, which prompted the Libyan government to intervene to prevent
} 49 | Int. J. of Multidisciplinary and Current research, Vol.6 (Jan/Feb 2018) 


\section{Conclusion}

1- The Islamic religion, like all the other heavenly religions, was revealed by Allah Almighty in His eloquent wisdom in the service of the human interest by bringing benefit to them and preventing evil from them.

2 - The Islamic religion does not contradict with the rest of the heavenly religions, but it is complementary to them as it is the last book of heaven that contains the mothers of the provisions that found in the books of the previous heavenly addition to other new provisions required by human maturity as a result of the evolution of time to serve their interests.

3 - The bad behavior of the human acts of worship and transactions were the cause of the existence of the Islamic religion and sending the Prophet Muhammad (peace be upon him) to change those customs, worship and transactions in the interest of human, from false to right, from darkness to light, and from spoil to interest.

4 - Since human behavior has become as an example of his religion, so it is necessary to distinguish between these behaviors: If they are bad are personal actions attributed to himself, and if valid are legitimate actions attributed to religion.

5 - The good behavior in word and deed mandated by the law must be maintained and used in dealing with others, Muslims and non-Muslims; because it is a means to reform others through the transfer of these behaviors to them, and be a good way to defend the Islamic religion.

6- Peace should be the basis of the Islamic religion to achieve peaceful coexistence among the different members of society regardless of religion, sex, color, and language and the preservation of their necessary interests. War may only be resorted to in the case of aggression because war is an exception and the results of the interest cannot be achieved. Moreover, the Sharia came to preserve interests not to destroy them.

7- There is no truth in calling of some tendencies to accuse the Islamic religion and the Messenger of Allah of violence and isolation and they have taken it as an excuse to abuse the Islamic religion, but this call is far from the truth as it is utterly, virtually and reportedly proven in The Holy Quran and Sunnah.

the demonstrators by force, four were killed and 34 wounded and the Marines were brought to protect the embassy. In Egypt, 224 demonstrators were injured by the Egyptian forces in front of the US Embassy, as well as in Tunisia, Egypt and Lebanon.

Due to the growing violence, foreign countries quickly denouncing and denouncing the film offensive to Islam, even the American government issued a statement of condemnation and the Vatican as well as the heads of bishops in the Arab countries to prevent bloodshed.
8 - Whenever the abuse of the Islamic religion and His Messenger appears, it shows the positive impact of the Islamic religion and dissemination to those communities and there is a desire in the members of the community to embrace the Islamic religion because they find the preservation of their interests in it, at the same time the tendentious persons use the worst means of abuse to keep people away from it.

9. Therefore, religion at all times and places is a means of reforming the people.

\section{References}

[1]. The Holy Quran

[2]. Altahrir waltanwir min altafsir: Muhamad bin Tahir Alashwr- Eihya Alturath house.

[3]. Tafsir Altabri: Muhamad bin Jarir bin Yazid bin Khalid altabri 'abu Jaefar t 310h - Alfikr Publishing house- Beirut- 1405h.

[4]. Tafsir Albaydawy: 'Abi Saeid Albaydawi Abdullah bin Omer bin Muhamad (685 h) Alfikr Publishing house- Beirut1416h - 1996A.C., Investigation: Abd Alqadir Arafat Alesha Hasuna.

[5]. Tafsir alqirtabi: aljamie liahkam al- Quran: Muhamad bin Ahmed bin Abi bikr bin Farih Alqurtobi Abi Abdullah (671 h) Alshaeb publishing house - Cairo - $2^{\text {nd }}$ issue 1372 hInvestigation: Ahmed Abd- Alalem Albardonni.

[6]. Tafsir Al- Quran aleazim: Ismaeil bin Omer bin Kathier Aldimashqii Abi Alfda' (774 h) - Alfikr Publishing houseBeirut- 1401h.

[7]. Fath Alqadir aljamie bayn faniyi alriwaya waldiraya min eilm altafsyr, Author: Muhamad bin Ali Alshuwkani.

[8]. Tafsir Aljalalin: Author: Jalal aldiyn Muhamad bin Ahmed Almahali, and Jalal aldiyn Abdularahman bin Abi Bakir Alsiwty, Publisher: alhadith house - Cairo, $1^{\text {st }}$ Edition.

[9]. Aldur Almanthwr: Author: Alfikr Publishing house- Beirut.

[10]. Al-Hadith Books:

[11]. Aljamea alsahih almokhtasar: Muhamad bin Ismaeil Abo Abdullah Albukhari Aljafi, Publisher: Ibn Alkathir house, Alyamama - Beirut - $3^{\text {rd }}$ Edition, 1407-1987. Investigation: Dr. Mustafaa Deeb Albiga Professor of Alhadith and its Science, Damascus University.

[12]. Aljamea alsahih sunan Altarmadhi Author: Muhamad bin Eisaa Abu Eisaa Altarmudhi Alsalami, Publisher: Ehya Alturath Alarabi house - Beirut, Investigation: Ahmad Muhamad Shakir and others - Alahadith tailed by Ahkam Alalbani.

[13]. Sunan Abi Dawd, Author: Sulayman bin Al'asheath Abu Dawud Alsyjstany Alazadi Publisher: Alfikr houe, Investigation: Muhamad Muhyialdiyn Abddulhamid- with the book: Comments of Kemal Yousif Alhout and the Hadiths tailed by Albany's provisions.

[14]. Sunan Albyhqy Alkubraa: Authors: Ahmad bin Alhusayn bin Ali bin Musaa Abu Bakr Albayhqi Publisher: Albaz house, Mecca 1414 - 1994 m, Invistigation: Muhammad Abdlqadir Ata.

[15]. Masned Al'imam Ahmad bin Hanbel: Al'imam Ahmad bin Hanbel Abi Abdullah Alshiybani (241 h) - Qurtuba corporation for publishing in Cairo.

[16]. Almanhaj sharah sahih Muslim bin Alhajaj, Author: Abu Zakria' Yahya bin Sharaf bin Maraei Alnawaw, Publisher: Ihya Alturath Alarabi house Beirut - $2^{\text {nd }}$ Edition, 1392. 
[17].Sahih Muslim: Muslim bin Alhajaj Abu Alhusayn Alqashiri Alnaysaburi Publisher: Ihya Alturath Alarabi house Beirut, Investigation: Muhamad Fuad Abdalbaqy.

[18]. Faqih Alsyrah: Dr. Muhamad Saeid Ramadan Albwty- $7^{\text {th }}$ Edition - Alsharq Aljadeed library - Bagdad.

[19]. Alsyra Alnabawya: Dr. Ali Muhamad Alsalaby- Almaerifa house, Beirut - Lebanon.

[20]. Almustadrik eala Alsahihin: Muhamad bin Abdullah Abi Abdullah Alhakim Alnaysaburi ( 405 h) - Alkutub Aleilmia house for publishing in Beirut- $1^{\text {st }}$ Edition, $1411 \mathrm{~h}-1990 \mathrm{~m}$ Investigation: Mustafaa Abdlqadir Ata with comments of Althahabi.

[21]. Al'adab Almufrad: Author: Muhamad bin Ismaeil Abu Abdullah Albukhari Aljafy, Publisher: Albashayir Al'islamia house - Beirut $3^{\text {rd }}$ Edition, 1409 - 1989, Investigation: Muhamad Fuad Abdalbaqi.

[22]. Almusanaf $\mathrm{fi}$ Al'ahadith walathar: Author: Abu Bakr Abdullah bin Muhamad bin Abi Shaybah Alkwfy, Publisher: Alrashid library, Riyadh $-1^{\text {st }}$ Edition 1409 , Investigation: Kamal Yousif Alhut.

[23]. Shuab Al'iman: Publisher: Abu Bakr Ahmad bin Alhusayn Albyhaqy, Publisher: Alkutub Aleilmia house for publishing in Beirut, $1^{\text {st }}$ Edition 1410, Investigation: Muhamad Alsaeid BasunY Zaghlul.

[24]. Majmae Alzawaed wa Manbae Alfawaed, Author: Noraldyn Ali bin Abi Bakr Alhaithamy, Publisher: Alfikr house, Beirut $1412 \mathrm{~h}$.

[25]. Umdat Alqari fi Sharah Albikhari: Badraldiyn Abu Muhamad Mahmud bin Ahmad Aleayni Investigation: Abdullah Mahmud Muhamad Omr, Publisher: Alkutub Aleilmia house for publishing in Beiru 2001.

[26]. Fawakih Aldawani ealaa risalat Ibn Abi Zayd Alqyrawany: Ahmad bin Ghanim bin Salim bin Mahna Alnafrawi Alazhari Almaliky, Investigation: Alshaykh Abdalwarith Muhamad Ali, Alfkir house for publishing.

[27]. Takhrij Ahadith Ihya Ulum Aldyn: Mahmud bin Muhamad Alhadad Abu Abdullah Alasima house for publishing 1987 Riyadh.

[28]. Books of Religion basics, call and jurisprudence

[29]. Al'ihkam fi Usul Alahkm: Ali bin Muhamad Alamadi Ab Alhasan (631 h) - Alkitab Alarabi for publishing Beirut, $1^{\text {st }}$ Edition 1404h, Investigation: Dr. Said Aljumaili.

[30]. Usul Albazdawi - Kanz Alwusul ilaa maerifat al'usul: Author: Ali bin Muhamad Albzdwy Alhanafy, Publisher: Jawid Press - Karachi.

[31]. Usul Alsarkhasi: Imam Shams Al'ayima Abi Bakr Muhamad bin Abi Sahl Alsarkhasi (490 h) - Almaerifa Publishing house in Beirut 1372h, Investigation: Abi Alwafa' Al'afghani.

[32]. Usul Alfaqih fi Nasijih Aljadiyd: Prof. Mustafaa Ibrahim Alzalmay- $5^{\text {th }}$ Edition 1999 m, Alkhansa company for limited publishing - Bagdad.

[33]. Irshad Alfuhul ilaa tahqiq alhaq min eilm alaswl: Muhamad bin Ali bin Muhamad bin Abdullah Alshawkani Alyamani Alsanani.

[34]. Al'ihkam fi Usul Alahkm: Ali bin Ahmad bin Hazm Alandalusi Abu Muhamad, Publisher: Alhadith house Cairo $1^{\text {st }}$ Edition, 1404.

[35]. Al'ibhaj fi sharah almunhaj eala munhaj alwusul 'ilaa eilm al'usul Baydawi, Author: Ali bin Abdalkafi AlsabkyPublisher: Alkutub Aleilmia house Beirut, $1^{\text {st }}$ Edition $1404 \mathrm{~h}$, Investigation: group of scholars.

[36]. Altamhid fi takhrij alfuru ealaa al'usul: Abdulrahim bin Alhasan Al'usnawi Abu Muhamad, Publisher: Alrisala corporation, Beirut $1^{\text {st }}$ Edition, $1400 \mathrm{~h}$, Investigation: Dr. Muhamad Hasan Hitu.

[37]. Alburhan fi aswl alfaqih, Author: Abdalmalik bin Abdullah bin Yousif Aljawini Abu Almaly, Publisher: Alwafa' -
Mansoura/ Egypt, $4^{\text {th }}$ Edition 1418h , Investigation: Dr. Abdalazim Mahmud Aldyb.

[38]. Altabsira fi aswl alfaqih, Author: Ibrahim bin Ali bin Yousif Alfiruzabady Alshiyrazi Abu Ishaq, Publisher: Alfikr house, Damascus $1^{\text {st }}$ Edition 1403, Investigation: Dr. Muhamad Hasan Hitu.

[39]. Almukhtasar fi aswl alfaqih ealaa madhab al'imam Ahmad bin Hanabel, Author: Ali bin Muhamad bin Ali Albaeli Abu Alhasan, Publisher: King Abdulaziz University, Makkah, Investigation: Dr. Muhamad Muzhrbiqa.

[40]. Almuafaqat fi aswl alfaqih: Ibrahim bin Musaa Allakhami Alghurnati Almalki, Publisher: Almaerifa house Beirut, Investigation: Abdullah Draz.

[41]. Almahsul fi eilm al'usul, Author: Muhamad bin Omar bin Alhusayn Alrazy, Publisher: Imam Muhammad Bin Saud Islamic University - Riyadh $1^{\text {st }}$ Edition $1400 \mathrm{~h}$, Investigation: Taha Jabir Fayad Alalwani.

[42]. Almustasfaa min eilm al'asul: Alimam Hujat Al'islam Muhamad bin Hamid Alghazali (445-505h), and kitab fawatih alrahmut- Al'arqam bin Abi Al'arqam house for publishing in Beirut.

[43]. Alfusul fi al'usul named usul aljasas, Author: Ahmad bin Ali Alraazi Aljasas, Publisher: Ministry of Awqaf and Islamic Affairs - Kuwait $1^{\text {st }}$ Edition, $1405 \mathrm{~h}$, Investigation: Dr. Ajeel Jasim Alnashmi.

[44]. Rawdat alnazir wajanat almanazr, Author: Abdullah bin Ahmad bin Qadama Almaqdisi Abu Muhamad, Publisher: Imam Muhammad Bin Saud Islamic University - Riyadh $2^{\text {nd }}$ Edition 1399h, Investigation Dr. Abdulaziz Abdulrahman Alsaeid.

[45]. Eilam Almuaqiein ean Rab alealamin, Author: Muhamad bin Abi Bakr Ayuwb Alzarey Abu Abdullah, Publisher: Aljil house - Beirut 1973, Investigation: Taha Abdulru'uf Saad.

[46]. Book of Christian Jurisprudence: Classification of the Rev. Abi Al-Faraj Abdullah Ibn Tayeb Al-Faqih in Christian Sciences and Laws, Reserved at the Catholic University Library - Milan

[47]. Awsul Aldawa, Author Dr. Abdulkarim Zaydan- Alrisal corporation for publishing and distribution Beirut Lebanon $9^{\text {th }}$ Edition $2002 \mathrm{~m}$

[48]. Lexical Linguistic books

[49]. Lisan Alarab, Author: Muhamad bin Mukaram bin Manthur Alafriqi Almasri, Publisher: Sadir house - Beirut $1^{\text {st }}$ Edition.

[50]. Alayn Book, Author: Abi Abdulrahman Alkhalil bin Ahmad Alfrahydi, Publisher: Alhilal library, Investigation: Dr. Mahdi Almakhzumi and Dr. Ibrahym Alsamray.

[51]. Anis Alfuqaha fi taerifat al'alfaz almutadawalat bayn alfuqaha', Author: Qasim bin Abdullah bin Amir Ali Alqwnwy, Publisher: Alwafaa house Jeddah $1^{\text {st }}$ Edition 1406h, Investigation: Dr. Ahmed Abdulrazaq Alkubaisi

[52]. Altaerifat, Author: Ali bin Muhamad bin Ali Aljarjani, Publisher: Alkitab Alarabi house Beirut $1^{\text {st }}$ Edition $1405 \mathrm{~h}$, Investigation: Ibrahym Alabyari.

[53]. Alhudud Al'aniqa waltaerifat aldaqyqa, Author: Zakaria bin Muhamad bin Zakaria Al'ansari Abu Yahya, Publisher: Alfik almueasir house Beirut $1^{\text {st }}$ Edition 1411h, Investigation: Dr. Mazin Almubarak

[54]. Almaghrib fi tartib almerib, Author: Abu Alfatih Nasiraldiyn bin Abd Alsydbn Ali bin Almatraz, Publisher: Osama bin Zaid library Aleppo $1^{\text {st }}$ Edition 1979 m, Investigation: Mahmud Fakhory and Abdulhamid Mukhtar.

[55]. Altawqif ealaa muhammat altaearif: Zainaldiyn muhamad alerwf beabdrawf bin Taj Alearifi bin Ali bin Zaynaleabdyn Alhadadi Almanawii Alqahry $10^{\text {th }}$ Edition $1990 \mathrm{~m}$, ealam alkutub for publishing Cairo. 